\title{
Trochę niezbyt udany debiut czyli słów kilka o eufemizmach w języku prasy i polityki na przykładzie języka francuskiego i polskiego
}

\author{
Malgorzata Izert \\ Uniwersytet Warszawski \\ m.izert@uw.edu.pl
}

\begin{abstract}
Streszczenie
$W$ artykule tym jest analizowane znaczenie kontekstowe czterech przysłówków trochę, nieco, mało, niezbyt oraz ich francuskich odpowiedników un peu, un (tout) petit peu, peu, pas trop we współczesnym języku prasy i polityki. Wedtug podstawowych definicji stownikowych stuża one do wyrażania słabego natężenia cechy. Dziennikarze nie chcac kogoś urazić, a politycy chcac lepiej wypaść, mówiąc o sobie samych, używaja ich, aby w sposób eufemistyczny powiedzieć o negatywnej cesze (trochę, nieco / un peu) albo aby prawie zanegować istnienie cechy pozytywnej (mało, niezbyt / peu, pas trop). Często jednak mówiąc mniej, dziennikarze czy politycy daja odczuć, że powiedzieli więcej. Litota - która sita rzeczy można dokładnie odczytać tylko $w$ kontekście użycia, jest zawoalowanym sposobem skrytykowania kogoś lub czegoś, wytknięcia poważnego niedociąnnięcia. Używa się jej dla wyrażenia silnego stopnia natężenia lub nawet nadmiaru cechy negatywnej.
\end{abstract}

Słowa kluczowe: eufemizm, litota, natężenie cechy, przysłówki

Abstract

A slightly unsuccessful debut or some remarks on euphemisms in the language of the press and politics on the example of French and Polish

In this article we analyze the context meaning of four adverbs: trochę, nieco, mało, niezbyt and their French equivalents un peu, un (tout) petit peu, peu, pas trop in contemporary press and political language. According to basic dictionary definitions, they are used to express weak intensity of a feature. The journalists, trying to avoid offending somebody, and politicians trying to make better impression while talking about themselves, use them, to talk about a negative feature in an euphemistic manner (trochę, nieco / un peu), or to "almost deny" the existence of a positive feature (mało, niezbyt / peu, pas trop). However, while telling less, the journalists or politicians often intend to make an impression that they said more. Litotes, which inevitably can be accurately understood only in the full context of use, is a 
veiled way to criticize someone or something, to point out a serious shortcoming. It is used to express a strong degree or even an excess of a negative feature.

Keywords: euphemism, litote, intensity of a feature, adverbs

\section{Wstęp}

Wydawałoby się, że w XXI wieku, w którym wolność słowa jest zagwarantowana konstytucyjnie, nie powinniśmy mieć żadnych oporów, aby nazywać rzeczy po imieniu. Jednak ciągle uciekamy się do eufemizmów, które są powszechne używane i, co ważniejsze, wybierane - poniekąd podświadomie - wtedy, gdy wyrażamy się w sposób oględny, nie chcąc kogoś urazić albo wtedy, kiedy już świadomie w sposób zawoalowany przemycamy coś więcej mówiąc mniej.

Przyczyny ich użycia są różne i wydaje się ciągle te same od wielu lat. Do najważniejszych należy zaliczyć, za St. Widłakiem (Widłak 1965: 72-78):

- przekonania religijne, przesądy, strach,

- konwenanse, dobre wychowanie, przyzwoitość, skromność, wstyd,

- delikatność, współczucie, litość,

ale też

- hipokryzję, próżność, osobisty interes.

Eufemizmy, jak widać z wymienionych powyżej przyczyn, mają podłoże pozajęzykowe, a funkcjonują na płaszczyźnie języka. Stanowią obszar badań niezwykle rozległy i interdyscyplinarny. Po pierwsze, wykazują związki z różnymi dziedzinami, m.in. psychologią, socjologią, szeroko rozumianą kulturą, antropologią, a także polityką oraz ekonomią. Po drugie, są wyrażane przez użycie najróżniejszych środków językowych - leksykalnych, morfologicznych, składniowych, stylistycznych, w sposób właściwy dla każdego języka. Po trzecie wreszcie, towarzyszą im nieodłącznie takie zjawiska językowe jak ekspresywność czy wartościowanie.

Przedmiotem tego artykułu jest analiza wybranych ze współczesnych tekstów prasowych i politycznych niektórych sposobów służących budowaniu eufemistycznych jednostek językowych, a mianowicie użycie przysłówków modyfikujących cechę, takich jak trochę, nieco, mało, niezbyt w języku polskim i ich odpowiedników w języku francuskim: un peu, un(tout) petit peu, peu, pas trop.

Zacznę od zacytowania wypowiedzi jednego z czytelników dziennika gazeta.pl, która zainspirowała mnie do rozważań nad eufemistycznym użyciem jednostek językowych: 
„Drodzy dziennikarze, troche zbyt często macie trudności ze zrozumieniem prostych słów, albo używanie hiperboli weszło wam w krew, i dlatego wszystko jest dla was »unikatowe«, »wyjątkowe«, »niezwykłe«" (wiadomosci.gazeta.pl, post czytelnika do artykułu „25. rocznica upadku Muru Berlińskiego”).

Czy rzeczywiście tylko wyrażenia hiperboliczne są stosowane w języku prasy a także w języku polityki? Czy dziennikarze, politycy stosują też inne środki językowe, które osłabiają, choć często tylko pozornie, dobitność mowy, przekazu?

\section{Podstawowe definicje}

Takie środki językowe, jak wymienione wcześniej przysłówki będące przedmiotem mojej analizy, tworzą figury stylistyczne: eufemizmy lub litoty, które łagodzą zazwyczaj ostrość wypowiedzi, ale też czasami, w sposób zawoalowany, wzmacniają jej dobitność.

\subsection{Eufemizm}

Eufemizm to termin pochodzenia greckiego, znaczy „dobrze brzmiący”. Według Słownika Języka Polskiego PWN to „słowo lub wyrażenie użyte zastępczo w celu złagodzenia wyrażeń drastycznych, dosadnych lub nieprzyzwoitych" (sjp.pwn.pl/eufemizm).

\subsection{Litota}

Litota jest „figurą retoryczną polegającą na zastąpieniu wyrażenia określającego cechę czegoś wyrażeniem przeciwstawnym zaprzeczonym, np. niemaly zamiast wielki" (sjp.pwn.pl/sjp/litota).

Według definicji umieszczonej w fiszkoteka.pl litota to:

„1. przeciwieństwo hiperboli; minimalizujące opisanie i pomniejszenie znaczenia jakiegoś zjawiska; także: celowa skromność mówcy w przedstawianiu siebie samego;

2. rodzaj eufemizmu: złagodzenie ostrości sądu przez zastąpienie jakiegoś określenia jego zaprzeczonym przeciwieństwem, np. niemały zamiast $d u \dot{z y}$ ” (fiszkoteka.pl).

Niektórzy językoznawcy, chociaż definicje słownikowe nie rozgraniczają jednoznacznie tych dwóch pojęć, widzą wyraźną różnicę między eufemizmem a litotą.

C. Romero (Romero 2016) uważa, że eufemizm jest rodzajem szczerego i grzecznego złagodzenia (atténuation polie et sincère) ostrości wypowiedzi (nie chcemy kogoś urazić), natomiast litota jest pozornym, o zabarwieniu ironicznym, złagodzeniem wypowiedzi 
(atténuation feinte et légèrement ironique), pod którym kryją się nasze prawdziwe, niezbyt pozytywne intencje.

Wydaje się jednak, że przy tak szeroko zdefiniowanych pojęciach nie zawsze jesteśmy $\mathrm{w}$ stanie określić, czy mamy do czynienia z eufemizmem czy z litotą. Czy szczerze, z dobrego serca autora, wypowiedź została złagodzona, czy wręcz przeciwnie, autor łagodząc swoją wypowiedź przez użycie takich a nie innych środków językowych, ukrył swoje nieszczere intencje i zamierza przekazać coś więcej lub coś odwrotnego niż to, co powiedział dosłownie.

Działanie obu figur stylistycznych oddaje dobrze łacińska sentencja: Fortiter in re, suaviter in modo: w rzeczy mocno, w sposobie lagodnie (Jarosz 2001: 661). Istotą użycia zarówno eufemizmu jak i litoty jest bowiem ,»opakowanie« nieprzyjemnej, trudnej lub wręcz wulgarnej treści w przyjemniejsze, bo omijające sedno brzmienie” (Stepaniuk, http://anglofan.felberg.pl/?dzial=8\&art=155). Wypowiedź jest złagodzona, choć czasami tylko pozornie.

\section{Analiza przysłówków trochę, nieco, mało, niezbyt i ich francuskich odpowiedników un peu, un petit peu, peu, pas trop}

Wybrane zostały tylko 4 przysłówki polskie i ich francuskie odpowiedniki. Nie są to jedyne przysłówki lub wyrażenia przysłówkowe, które mogą być użyte do tworzenia eufemizmów lub litot. Nie wszystkie jednak łączą się z przymiotnikami. Poza tym, analiza użycia wszystkich możliwych synonimów 4 wybranych przysłówków wykroczyłaby poza limit arkuszy przyjęty dla artykułu w czasopiśmie naukowym.

\subsection{Materiał badawczy i sposób utworzenia korpusu}

Przysłówki były wyszukiwane za pomocą wyszukiwarki google.pl (dla języka polskiego) i google.fr (dla języka francuskiego) z opcją przeszukiwanie zaawansowane, ograniczone do wybranych domen gazeta.pl i rp.pl dla języka polskiego oraz lemonde.fr i liberation.fr dla języka francuskiego, na przykład: „trochę” (site:gazeta.pl) lub „un peu” (site:lemonde.fr) bez wskazania ram czasowych. Wybrane zostały tylko teksty powstałe po 2010 roku.

Tak zebrany korpus tekstów z interesującymi nas przysłówkami posłużył jako materiał do analizy eufemistycznego użycia tych przysłówków. Dla zilustrowania konkretnego użycia danego przysłówka w języku polskim i odpowiadającego mu przysłówka w języku francuskim został wybrany jako przykład najbardziej reprezentatywny (dla każdego języka) i omówiony w tym artykule tylko jeden kontekst użycia. 


\subsection{Trochę, nieco / un peu, un (tout) petit peu + Adj. [+negatywny]}

Przysłówki te połączone z przymiotnikami, najczęściej nacechowanymi negatywnie, wskazują na niewielkie natężenie cechy. Cecha modyfikowana przez trochę, nieco / un peu, un (tout) petit peu znajduje się nieco poniżej implicytnej normy, nie osiąga pełnego natężenia, dąży do normy, ale jej nie osiąga.

Figura 1: Słabe natężenie cechy: trochę, nieco / un (tout petit) peu.

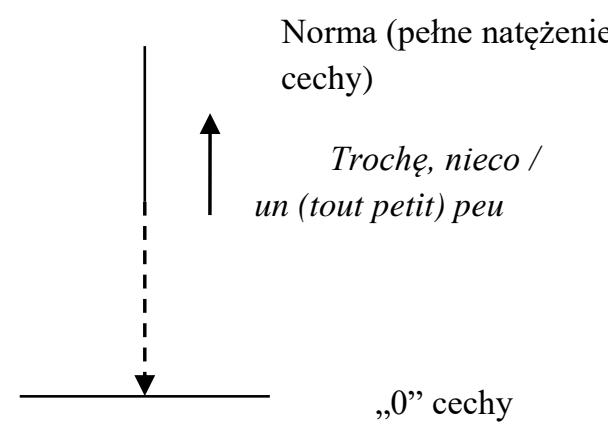

$\mathrm{W}$ rezultacie przymiotnik nacechowany negatywnie $\mathrm{w}$ połączeniu $\mathrm{z}$ troche, nieco / un (tout petit) peu wydaje się być „mniej” negatywny: trochę głupie rozumowanie (un raisonnement un peu bête), wydaje się być mniej głupie niż głupie rozumowanie (un raisonnement bête). Przysłówek eufemizuje, łagodzi wartość przymiotnika nacechowanego negatywnie.

Znaczenie trochę / un peu + Adj. [+negatywny] to osłabiona afirmacja (affirmation atténuée) (Ducrot 1972: 199) cechy negatywnej.

Usytuowanie na skali cechy modyfikowanej przez trochę / un peu wyglądałoby następująco:

troche glupi $\rightarrow$ glupi $\rightarrow$ bardzo glupi.

Możliwe znaczenia kontekstowe dla troche, nieco / un peu, un(tout) petit peu jakie udało się znaleźć w zebranym korpusie to:

1. Wskazanie na słaby, ale nie bez znaczenia, stopień natężenia cechy. Cecha nie osiągnęła pełnego natężenia. Jej intensywność jak też wartość aksjologiczna są nieco osłabione (osłabienie afirmacji): trochę głupi = 'nie całkiem głupi';

[pol. 1] „W spocie wyborczym PO Janusz Lewandowski, komisarz UE ds. budżetu wspólnie z Jerzym Buzkiem, Donaldem Tuskiem i Radosławem Sikorskim obiecywał walkę o 300 mld zł z UE. Zapytany o to na spotkaniu w jednym z liceów w Lublinie, Lewandowski odpowiedział z zaskakującą szczerością - Brałem udział w tych nieco durnych klipach, ale to byla kampania - relacjonuje Dziennik Wschodni” (wiadomości.gazeta.pl) (osłabiona afirmacja: nieco durnych klipach = 'nie całkiem durnych klipach').

[fr. 1] Tytuł: „La carte de séjour «gold» est «un peu élitiste», reconnaît Besson”. 
Wypowiedź ministra Besson na temat »złotej karty pobytu«: »C'est vrai, c'est un peu élitiste [...] cette carte ne va pas s'appliquer à l'artisan ou à la personne qui crée sa petite entreprise«, a reconnu le ministre, qui s'est dit »conscient des critiques adressées à ce dispositif« [...] (liberation. fr.) (osłabiona afirmacja: ta karta jest trochę elitarna = 'częściowo elitarna').

2. Eufemistyczne (nie chcemy kogoś urazić) wyrażenie naszego zdania na jakiś temat. [pol. 2] Tytuł: „Młodzieżowy radny: czujemy się trochę zlekceważeni”.

„Płocczanin Dawid Penkala opowiada o swoim rozczarowaniu związanym z Młodzieżową Radą Miasta i tym, że wydaje się ona być nikomu niepotrzebna. (plock.gazeta.pl) (czujemy się trochę zlekceważeni = 'czujemy się zlekceważeni').

[fr. 2] Grégoire Biseau, dziennikarz rubryki polityka w Libération: On ne peut pas taxer Libération d'avoir été des valets de Nicolas Sarkozy, mais laisser entendre que Sarkozy a choisi de faire la guerre en Libye pour faire monter sa cote de popularité me paraît être un tout petit peu caricatural (liberation.fr) (nieco karykaturalne = 'karykaturalne').

3. Celowe, zamierzone osłabienie wypowiedzi. W rzeczywistości chcemy, żeby rozmówca zrozumiał coś odwrotnego (litota). Wypowiedź z użyciem trochę, nieco / un peu, un petit peu nie jest osłabioną, lecz wręcz wzmocnioną afirmacją.

[pol. 3] Podpis pod zdjęciem: Nowa inwestycja ucieszy kierowców i nieco mniej rowerzystów (sosnowiec.wyborcza.pl) [wyremontowana szosa, a wzdłuż niej pas ziemi dopiero przygotowywany pod ścieżkę rowerową] (ucieszy [...] nieco mniej rowerzystów = 'nie ucieszy rowerzystów', 'zmartwi rowerzystów').

[fr. 3] Jean-Marie Le Pen a jugé, mardi 30 décembre, »étonnant« et »un petit peu choquant « de voir Dieudonné faire remettre à Robert Faurisson le "prix de l'infréquentabilité et de l'insolence« par une personne déguisée en déporté juif [...] (lemonde.fr) (nieco szokujące = 'bardzo szokujące').

4. Celowa minimalizacja własnej osoby, zwłaszcza własnych poglądów, wartości, też sytuacji, w jakiej się wypowiadający podmiot znajduje, itp.

[pol. 4] Tytuł: „Paweł Hajncel: jestem trochę anarchistą”.

Spodobały mi się wszelkie niezależne działania. Unikam środowisk, w których ludzi nie trzyma nic poza pieniędzmi. Angażuję się w każde niezależne działanie, bo jest to zdrowy oddech.” (lodz.gazeta.pl) (skromność oratorska: jestem trochę anarchistą = 'jestem archaistą'). [fr. 4] Deklaracja wydawcy Le Point, Claude'a Imberta: „Il faut être honnête. Moi, je suis un peu islamophobe. Cela ne me gêne pas de le dire" (libération. fr.) (skromność oratorska: jestem trochę islamofobem $=$ 'jestem islamofobem'). 
5. Wyrażenie opinii (szczere lub ironiczne) o nadmiernym natężeniu cechy. Natężenie cechy wykracza poza dopuszczalną granicę normy i wskazuje na nadmiar cechy.

[pol. 5] Tytuł: „Trochę ciszej, panie reżyserze”.

Sobotnia premiera Teatru Muzycznego w Poznaniu „Dookoła karuzeli, czyli dziecko potrafi” to najgłośniejszy spektakl, na jakim byłem. Ostatnio czułem się tak, gdy odbierałem córkę ze szkoły podczas dużej przerwy (poznan.gazeta.pl) (trochę ciszej, panie reżyserze = 'za głośno, panie reżyserze').

[fr. 5] Wypowiedź, instruktora pływania z gimnazjum, Michela Perroux na temat kariery pływaczki Camille Mufat: „C'est toujours un peu difficile de lire le futur d'une sportive dans une discipline où des semaines et des semaines d'entraînement ne débouchent jamais que sur 1 ou 2 centièmes" (libération.fr) (jest trochę trudno przewidzieć przyszłość = 'zbyt trudno przewidzieć przyszłość’).

\subsection{Malo, niezbyt / peu, pas trop + Adj. [+pozytywny]}

Przysłówki mało niezbyt / peu, pas trop połączone z przymiotnikami nacechowanymi pozytywnie również wskazują na niewielkie natężenie cechy. Modyfikowana cecha znajduje się poniżej implicytnej normy, ale nie dąży do osiągnięcia pełnego natężenia (osiągnięcia normy), jak ma to miejsce w przypadku połączenia z trochę, nieco /un peu, tylko się od niej oddala. Stopień natężenia cechy jest tak słaby, że zbliża się do zera.

Figura 2: Słabe natężenie cechy: mało / peu.

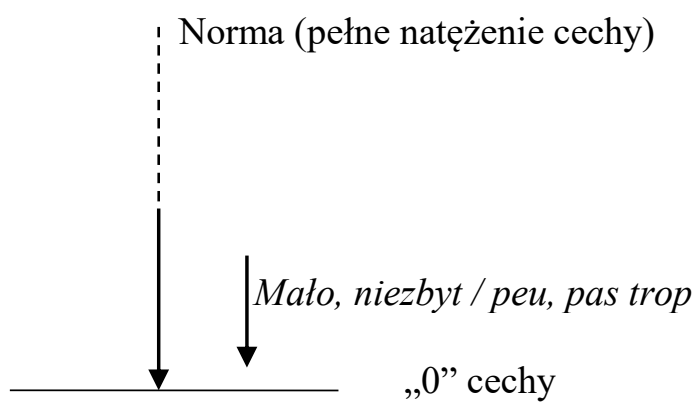

$\mathrm{W}$ rezultacie przymiotnik nacechowany pozytywnie $\mathrm{w}$ połączeniu $\mathrm{z}$ mało, niezbyt/ peu, pas trop traci wartość pozytywną: mało, niezbyt inteligentny /peu, pas trop intelligent zmierza do nieinteligentny (non inteligent) / glupi (bête) [+negatywny].

Znaczenie: mało, niezbyt/ peu, pas trop + Adj. [+pozytywny] to osłabiona negacja (négation atténuée) (Ducrot: op.cit.) cechy pozytywnej.

Usytuowanie na skali modyfikowanej cechy wyglądałoby następująco:

inteligentny $\rightarrow$ mato inteligentny $\rightarrow$ zero inteligencji $=$ nieinteligentny 
W zebranym korpusie tekstów dla tej pary przysłówków zostały wyróżnione tylko 2 znaczenia kontekstowe:

1. Mało, niezbyt / peu, pas trop wskazują na bardzo słaby stopień natężenia cechy. Natężenie jest bliskie zera, a wartość pozytywna cechy prawie zanegowana (osłabienie negacji):

Mało/niezbyt inteligentny $=$ 'prawie „0” inteligencji, prawie nieinteligentny', żeby nie powiedzieć 'głupi'.

[pol. 6] Tytuł: „Niezbyt hermetyczny mur. Na Węgry i tak dotrze 300 tys. imigrantów” (wiadomosci.onet.pl) (osłabienie negacji: niezbyt hermetyczny = 'prawie niehermetyczny, nieszczelny').

[pol. 7] „Wrocławski prototyp, którego budowa zakończyła się w 1967 roku, okazał się jednak mało udany. [...] W połowie lat 70-tych stalowe liny, na których opierała się cała konstrukcja, trzeba było wzmocnić betonem [...]. Ostatecznie ideę wiszących domów odwieszono na kołek. Tym sposobem pierwszy polski trzonolinowiec stał się jednocześnie ostatnim" (wroclaw.wyborcza.pl) (osłabienie negacji: mało udany prototyp = "prawie nieudany, niewydarzony').

[fr. 6/7] La Commission européenne a jugé, vendredi 26 février à Bruxelles, „peu satisfaisant" le fonctionnement du marché du travail [...] (lemonde. fr) (osłabienie negacji: mało satysfakcjonujące $=$ 'prawie niesatysfakcjonujące funkcjonowanie rynku pracy'.

2. Szczere lub zamierzone (o zabarwieniu ironicznym) osłabienie wypowiedzi, która ma być odebrana przez adresata jako pełna negacja a nie osłabienie negacji:

[pol. 8] Tytuł: „Korea Północna obraziła Clinton: Zabawna, ale mało inteligentna pani...” (wiadomosci.gazeta.pl) (zamierzone o zabarwieniu ironicznym osłabienie wypowiedzi, pełna negacja: mało inteligenta $=$ 'nieinteligentna, niemądra' $=$ 'głupia').

[pol. 9] Taki spadek jest naprawdę mało ważny w stosunku do ceny akcji (pieniadze.gazeta.pl) (pełna negacja: mało ważny spadek cen akcji ='nieważny, nieistotny, niewiele znaczący, bez znaczenia').

[fr. 8/9] „Il y aura une ouverture du capital”, assure Riss (le directeur de Charlie Hebdo), tout en reconnaissant s'être déclaré «pas trop favorable» à ce que «tout le monde détienne des parts de façon directe» (lemonde.fr.) (zamierzone osłabienie wypowiedzi, pełna negacja: niezbyt przychylny = 'wcale nieprzychylny'). 


\subsection{Połączenie przyslówków trochę z zbyt, niezbyt i un peu z trop i pas trop}

W obu językach przysłówki, odpowiednio dla języka polskiego trochę i dla francuskiego un peu, łączą się zarówno z przysłówkiem zbyt (jęz. pol.), trop (jęz. fr.) jak i niezbyt (jęz. pol.), pas trop (jęz. fr.).

W przypadku połączenia trochę zbyt (jęz. pol.) / un peu trop (fr.), pierwszy przysłówek wskazujący na słaby stopień natężenia cechy (ale to natężenie wzrasta) łączy się z przysłówkiem wskazującym na nadmiar cechy.

Usytuowanie na skali cechy modyfikowanej przez oba przysłówki wyglądałoby następująco:

wystarczająco (natężenie cechy w normie) $\rightarrow$ trochę zbyt (umiarkowany nadmiar) $\rightarrow$ zbyt (nadmiar)

Trochę w połączeniu z przysłówkiem zbyt ma dwa znaczenia kontekstowe:

1. Nadmiar cechy nie jest anulowany przez trochę - trochę zbyt glośny to ciągle zbyt glośny, ale jest on nieco osłabiony. Połączenie tych dwóch przysłówków wskazuje więc na umiarkowany nadmiar cechy:

[pol. 10] Recenzja filmu Party Girl: „Film jest trochę zbyt przewidywalny, zmierzający do rozwiązania, które widać na odległość, ale ujmująco prawdziwy, szczery i autentyczny" (warszawa.gazeta.pl/warszawa) (= 'umiarkowanie zbyt przewidywalny').

[fr. 10] Tytuł: „Des manuels encore un peu trop blancs”[...] la Haute Autorité de lutte contre les discriminations et pour l'égalité (Halde) publie, jeudi 6 novembre, une grande enquête sur la place des stéréotypes et des discriminations dans les manuels scolaires. (lemonde.fr.) (= 'umiarkowanie zbyt białe' = podwójny eufemizm: biate zamiast rasistowskie) .

2. Dziennikarz lub polityk mówi: 'X jest trochę zbyt Adj./ Adv.' i robi to przez grzeczność (eufemizm) albo żeby dać do zrozumienia, że chodzi mu o więcej (litota): 'X jest zbyt Adj. / Adv.'

[pol. 11] Jan Rokita W Sieci: „Wizyta Obamy dała Amerykanom trochę zbyt latwą okazję do odnowienia wpływów nad Wisłą za niewielką cenę" (wpolityce.pl) (= zbyt łatwa, za łatwa okazja).

[fr. 11] Tytuł: „Une image de la Russie un peu trop Rouge pour être honnête” (lemonde.fr) artykuł na temat wystawy prezentowanej w Amsterdamie przez Olgę Sviblovą, dyrektora Muzeum MAMM w Moskwie (= zbyt czerwony wizerunek Rosji). 
Kiedy trochę (fr. un peu), przysłówek oznaczający słabe, ale wzrastające natężenie cechy łączy się z przysłówkiem niezbyt (fr. pas trop) wskazującym na słabe, bliskie zeru, natężenie cechy mamy do czynienia z podwójnym osłabieniem negacji:

nieudany debiut (negacja udanego debiutu) $\rightarrow$ niezbyt udany debiut (osłabienie negacji) $\rightarrow$ trochę niezbyt udany debiut (podwójne osłabienie negacji).

Najczęściej jednak w wypowiedziach polityków połączenie tych dwóch przysłówków to tylko złagodzona forma powiedzenia nie wprost o negatywnych cechach kogoś lub czegoś. [pol. 12] Tusk: Nie namówią mnie na błogostan. Byli wśród nich mądrzy i głupi, wierzący i niewierzący, uczciwi i może trochę niezbyt uczciwi... (= (bardzo) nieuczciwi, nieprawi itp.) (m.wiadomosci.gazeta.pl).

[fr. 12] Je suis désolée de dire que moi aussi j'estime Widad Kefti - vous avez présenté une vision un peu pas trop subjective de la situation, en ne donnant que les commentaires de la LDJ, ce qui n'est pas une référence, déjà... (libération.fr) (= niesubiektywny opis sytuacji).

\section{Wnioski}

Zarówno w języku polskim jak i francuskim, aby w sposób eufemistyczny powiedzieć o negatywnej cesze, poprzedzi się przymiotnik głupi, zazdrosny (fr. bête, jaloux), itp. przysłówkami trochę, nieco (jęz. pol.) / un peu, un (tout) petit peu (jęz. fr.).

W obu językach, aby uniknąć użycia przymiotnika nacechowanego negatywnie, zazwyczaj zaprzeczonego przymiotnika o wartości pozytywnej, wybiera się często przysłówki mało, niezbyt (jęz. pol.) / peu, pas trop (jęz. fr.) + przymiotnik o wartości pozytywnej, np. niezbyt mądry, niezbyt zręczny zamiast niemądry, niezręczny (jęz. pol.) / peu raisonnable, pas trop adroit zamiast déraisonnable, maladroit (jęz. fr.).

Trochę zbyt + Adj. [+negatywny] / trochę niezbyt + Adj. [+pozytywny] mają swoje dość dokładne odpowiedniki w języku francuskim: un peu trop i un peu pas trop. Za każdym razem trochę służy eufemistycznemu wyrażeniu bądź nadmiernego natężenia cechy, np. trochę zbyt łatwa okazja = 'zbyt łatwa, za łatwa okazja' bądź eufemistycznemu wyrażeniu cechy niepożądanej (negatywnej), np. trochę niezbyt uczciwy = '(bardzo) nieuczciwy'.

Odpowiadając za dziennikarzy na postawiony im przez jednego z czytelników zarzut a mianowicie, że używają oni trochę za dużo i trochę za często wyrażeń hiperbolicznych (Mega afera!, Wielki biznes... Niesamowity projekt... Wspaniały koncert...) można stwierdzić, że zarówno dziennikarze jak i politycy dość często uciekają się też do tropów takich jak litota, która jest przeciwieństwem hiperboli. Czasami jest to zabieg wskazujący na 
celową skromność (prawdziwą lub udawaną) mówcy (polityka) w przedstawianiu siebie samego. Innym razem jest to sposób na zbagatelizowanie poważnej wady osoby, którą mówca (polityk lub dziennikarz) chce bronić (także własnej wady).

Dziennikarze czy politycy mówiąc mniej, chcą też często powiedzieć więcej. Litota, która siłą rzeczy daje się dokładnie odczytać tylko w kontekście użycia, jest zawoalowanym sposobem skrytykowania kogoś lub czegoś, wytknięcia poważnego niedociągnięcia. Używana jest dla wyrażenia silnego stopnia natężenia cechy lub nadmiaru cechy negatywnej. Powie się:

Trochę niezbyt rozgarnięty, aby nie powiedzieć wprost nierozgarnięty / bardzo nierozgarnięty;

Troche / nieco roztargniony, aby nie powiedzieć wprost roztargniony, bardzo roztargniony a nawet zbyt roztargniony;

Niezbyt udany projekt, aby nie powiedzieć nieudany projekt / kompletnie chybiony projekt, itd.

Tylko kontekst użycia pozwala odczytać, czy dany przysłówek posłużył do osłabienia dobitności mowy czy raczej posłużył, nie wprost, do wzmocnienia wypowiedzi w myśl cytowanej sentencji łacińskiej: w rzeczy mocno, w sposobie łagodnie.

\section{Bibliografia}

Ducrot, Oswald (1972) „»Peu« et »un peu«”. [W:] Dire et ne pas dire. Principes de sémantique linguistique. Paris: Hermann; 191-220.

Jarosz, Mirosław (2001) Słownik wyrazów obcych. Irena Kamińska-Szmaj (red. nauk.). Wrocław: Wydawnictwo Europa.

Romero C. (2016) - materiały z korespondencji prywatnej.

Stepaniuk, Aldona „Angielskie eufemizmy”. Czasopismo periodyczne grupy Felberg. [pobrane z http://anglofan.felberg.pl/?dzial=8\&art=155. Data ostatniego dostępu: 10.01.2016]

Widłak, Stanisław (1965) „Zagadnienie tabu i eufemizmu w językach romańskich”. [W:] Kwartalnik Neofilologiczny, z. 12; 73-79.

fiszkoteka.pl (konsultowane 10.01.2016)

gazeta.pl (konsultowane 10.01.2016 - 10.03.2016)

lemonde.fr (konsultowane 10.01.2016 - 10.03.2016) 
liberation.fr (konsultowane 10.01.2016 - 10.03.2016)

rp.pl (konsultowane 10.01.2016 - 10.03.2016)

sjp.pwn.pl (konsultowane 10.01.2016) 